\title{
A Case Study of Partners in Educational Change: Teacher-librarians and Pre-service Teachers
}

\author{
Marlene Asselin
}

\author{
Faculty of Education \\ University of British Columbia \\ Canada
}

\section{Jo-Anne Naslund}

\section{Education Library \\ University of British Columbia \\ Canada}

\begin{abstract}
This case study aimed to clarify the role of the teacher-librarian and the nature of the school library program to pre-service teachers. Nineteen pre-service teachers collaboratively planned curriculum with teacher-librarians in their practicum schools. Data consisted of pre- and post-experience concept maps and interviews with all participants. Results showed pre-service teachers (a) significantly increased their knowledge of collaboration, resource-based learning, and information literacy, and (b) learned that collaboration helps refine and extend their teaching ideas. Teacher-librarians identified flexible scheduling and collaborative culture as conditions for curriculum-based library programs. Authentic experiences with teacher-librarians appear to be a promising means of preparing new teachers as partners.
\end{abstract}

\section{Introduction}

It's not the way teaching is done, unfortunately. We don't collaborate with each other. It's an individual craft that you do in the privacy of your own room with the door shut usually, and you don't have opportunities to have conversations about the same kids on the same assignment with two professionals looking at the work at the same time. (Clark et al., 1996, p. 217)

Today, as the library media specialist's role becomes even more closely linked with the curriculum, the significance of collaboration throughout the learning process is increasingly important. Collaboration is essential as library media specialists work with teachers to plan, conduct, and evaluate learning activities that incorporate information literacy. (American Association of School Librarians \& Association for Educational Communications and Technology, 1998, p. 50)

Voices of teachers and voices of teacher-librarians; how will the two ever meet to work together to support student learning? This paper describes a project that educates preservice teachers about collaborative planning with teacher-librarians for the purpose of developing resource-based units of study and integrated information literacy instruction. 


\title{
Part V. Contributors
}

\section{Contributors to the Fourth International Forum on Research in School Librarianship}

\begin{abstract}
Abrizah Abdullah has worked in a number of schools as well as the Educational Policy Planning and Research Division. Ministry of Education in Malaysia. She is currently a Lecturer at the Faculty of Computer Science and Information Technology at the University of Malaya in Kuala Lumpur, Malaysia. Email: abrizah@fsktm.um.edu.my.
\end{abstract}

Marlene Asselin is a member of the Department of Language and Literacy Education in the Faculty of Education at the University of British Columbia, Canada. She coordinates the Diploma and Graduate Programs in Teacher-Librarianship, and her research areas of interest include reader response, resource-based learning, and the social dimensions of literacy. Email: marlene.asselin@ubc.ca.

Susan Gibson is Associate Professor in the Faculty of Education at the University of Alberta, Canada. Her ongoing research includes studies of collaborative research and the implementation and integration of the Internet into elementary and secondary schools. Email: sgibson@ualberta.ca.

Ken Haycock is Director of the graduate School of Library Archival and Information Studies at the University of British Columbia in Vancouver, Canada. He has been a teacher, teacher-librarian, and school principal as well as senior education official. From 1995-1997 he was the elected chair of the West Vancouver (Canada) School Board, and from 1995-2000 he served as Executive Director of the International Association of School Librarianship. Email: ken.haycock@ubc.ca

James E. Herring is Head of the Department of information Management at Queen Margaret University College, Scotland. He is the author of books and articles on school librarianship, information skills, and the use of the Internet in schools. He is currently researching the impact of school intranets on the role of the school librarian. Email: iherring@QMUC.ac.uk.

Eleanor B. Howe has served as librarian and taught in both elementary and secondary schools in the United States. Her interests include action research, implementing technology, and creating school library programs that contribute to the learning of students. She has published and presented articles and sessions at the local, state, national, and international levels. Email: howe@washington.k12.pa.us; ehowe@bellatlantic.net.

Jo-Anne Naslund is the Instructional Programs Librarian at the Education Library in the Faculty of Education at the University of British Columbia, Canada. She has worked as a teacher-librarian and a teacher of English and physical education. Her research interests include resource-based learning, reading interests, and children's literature. Email:

Joanne.naslund@ubc.ca. 
Visions of learner-centered libraries are grounded in partnerships with all members of the educational community and school library programs fully integrated with curriculum (American Association of School Librarians \& the Association for Educational Communications and Technology, 1998). While teacher collaboration is a characteristic of effective schools (Taylor, Pearson, \& Richardson, in press) and a focus of school reform (Fullan, 1991,1993), less than one-third of teachers collaborate with teacherlibrarians (National Center for Educational Statistics, 1994). Haunting many current practices are historical conceptions of the school library program and teacher-librarian that separate them from the school's curriculum and its teachers (Jackson, Herling, \& Josey, 1976). Even a recent article in a professional literacy journal claims, "whereas in the event of an emergency, a school's library and librarian could be done without, few schools could exist without classrooms or teachers" (Dressman, 1997, p. 267). The American Library Association's Presidential Committee on Information Literacy (1989) recognized that the information age is divorced from most teaching styles and recommended that "teacher education and performance expectations should be modified to include information literacy concerns ... a portion of the practicum or teaching experience of beginning teachers should be spent with library media specialists" (Committee Recommendations \#5).

While there have been advocacy efforts aimed at in-service teachers, pre-service teachers remain a sorely overlooked group of partners (Haycock, 1996; Oberg, 1999). Doiron (1999) advocates that educators in positions with Ministries of Education and universities, with their unique perspectives, take a more active role in developing new partnerships with our school libraries. The project described in this paper is an example of one way faculties of education are preparing new teachers for the Information Age.

In 1998 the Information Literacy Project was established in a large Canadian teacher education program to the support the development of learner-centered, curriculum-based school library programs through the formation of partnerships between pre-service teachers and teacher-librarians. The goal was to introduce pre-service teachers to inquiry-based integrated unit planning and information literacy pedagogy through collaboration in school library programs. Specific objectives of the project were to increase pre-service teachers' knowledge of (a) the role of the teacher-librarian as instructional partner, (b) integrated collaborative school library programs, and (c) information literacy skills. Pre-service teachers learned about these concepts and skills through first-hand collaborative experiences with teacher-librarians.

\section{Collaboration, Resource-based Learning, and Information Literacy: A Brief History of School Library Programs}

Initial attempts to broaden the mission of the school library to include more than circulation of materials and provision of reading guidance occurred during the 1960's. With the introduction of resource-based learning and cooperative planning and teaching, the school library and teacher-librarian moved to an integral position within the school's instructional program, and Canadian and American publications designated a new mission for school libraries: to ensure that students and staff are effective users of 
information (CSLA, 1988; AASL\& AECT, 1988). In subsequent years, a growing body of research demonstrated that student expertise in accessing, evaluating, and using information positively influence student learning (AASL \& AECT, 1998, pp. 1 - 7). The current guidelines in the United States explicate information literacy standards and encourage the teacher-librarian to collaborate with teachers (AASL \& AECT, 1998).

For nearly 40 years teacher-librarians have been promoting and implementing collaborative models of resource-based learning. In this method, teachers and teacherlibrarians coach students and actively engage them in structuring meaningful inquiries and constructing knowledge through the use of multiple resources. It is a method recommended for both teachers (Short et al., 1996) and teacher-librarians (AASL, 1999). Resource-based learning is also the primary means by which students' information literacy is developed. When teachers and teacher-librarians collaboratively plan and teach resource-based units that are grounded in core curriculum, they address the skills and strategies students need to use information resources effectively. The Canadian document, Students' Information Needs in the $21^{\text {st }}$ Century: Competencies for Teacherlibrarians (ATLC \& CSLA, 1997) states, "The teacher-librarian provides leadership in collaborative program planning to ensure both physical and intellectual access to information and commitment to voluntary reading." Similarly, the American Association of School Librarians (1999) highlights both the collaboration between teachers and teacher-librarians, and the integration of information literacy skills in authentic learning contexts.

\section{Teacher Knowledge}

Teachers' beliefs are central to how they teach (Shulman, 1987) and starting points in learning to teach (Richardson, 1997). Research in pre-service teachers' beliefs shows that their past experiences with teaching, learning, and curricular areas have a significant influence and act as filters for their coursework and practicum experiences (Borko \& Putnam, 1996). Teacher education is seen as a "critical period" for the development of alternative beliefs consistent with current views of teaching and learning (Powell, 1996). What most effectively guides reformulation of pre-service teachers' beliefs is explicating their entry beliefs alongside learning and supportive practice. Constructivist approaches to teacher education assume that each student must construct their own understandings by identifying their own personal beliefs and modifying those as they work with new experiences and information.

Given the influence of teachers' past experiences, it is not surprising that teacher knowledge about the role of the teacher-librarian and library program appears to reflect past notions of the teacher-librarian as provider of resources or instructor of decontextualized library skills and of the school library as warehouse (Craver, 1986). In a recent survey of 40 elementary teachers, Moore (2000) found that teachers are unclear about the meaning of information literacy and equate information literacy with older 
notions of library or research skills. The results of Moore's survey also revealed teachers' undeveloped understandings about how to effectively plan resource-based learning. Finally, Moore found that teachers were unsure about the role of the school library program in student learning.

Pickard (1993) noted that teachers have had few opportunities to see strong models of instructional partnerships. The results of this state-wide survey showed that although library media specialists understand the importance of the instructional consultant role, only ten percent carry out the role at Loertscher's (1988) higher level where joint planning, teaching, and evaluating of resource-based curriculum units occur and where leadership in curriculum development is evident. Similarly, McCarthy (1997) found that implementation of Information Power was constrained in many schools by such factors as budget, scheduling, and lack of administrative support. These findings imply that teachers are exposed to limited models of effective school library programs.

In the province where this Information Literacy Project was implemented, a number of political factors have been threatening the existence of school libraries and the morale of teacher-librarians. Positive developments, such as new Ministry requirements during the past two years, have been reversing this trend and have increased the need for education about the school library in pre-service programs.

\section{The Research}

The case study reported in this paper is an extension of the Information Literacy Project that initially started within the context of a required elementary language arts course for pre-service teachers $(\mathrm{K}-8)$ during the second term of their post-baccalaureate teacher education program. In this project, pre-service teachers learned first-hand about the role of the teacher-librarian and how to collaboratively plan a resource-based unit of study for use in their practicum. Learning environments during the first two years of the project were the university classroom and two of its libraries where teacher-librarians at the university and volunteer teacher-librarians from the community came to work with preservice teachers. Effects of these experiences on pre-service teachers' understandings of the school library program and the role of the teacher-librarian were tracked both years. Results reported for the first two years of the project showed positive effects on preservice teachers' understandings (Asselin, 1999).

Despite this success, questions remained. Were pre-service teachers enacting the new knowledge they had gained in real school settings? And if so, how were they enacting this new knowledge? During the third year of the project, the basic structure of the project was adapted to meet two purposes: (a) to increase authenticity of the planning periods, and (b) to support transfer of the course-derived learning to application during school practicum. In these adaptations, pre-service teachers collaboratively planned their resource-based units with the teacher-librarian in the schools where they would be doing their spring practicum. Four extension projects were conducted in four school districts. This paper reports a case study of one of the four extension projects. 


\section{Methodology}

\section{Participants}

The pre-service teachers were members of one cohort $(n=19)$ enrolled in the required elementary $(\mathrm{K}-8)$ language arts course in one of Canada's largest teacher education programs. All pre-service teachers held bachelor degrees and spoke English as their first language. There were six males and thirteen females. The pre-service teachers lived in or near the school district associated with the cohort, and most hoped to get a job in that district upon completion of the program. Dr. Asselin served as both course instructor and researcher; such a dual role was seen in other studies of pre-service teachers' knowledge (Finke \& Edwards, 1997; Wolf et al., 1996).

Four female teacher-librarians participated in the study. All had at least two years teaching experience, and their experience as a teacher-librarian ranged from less than one year to more than ten. Three held part-time positions and one held a full-time position. All four were involved in district professional development to upgrade their teacherlibrarian qualifications. This program, in its second year, consisted of six diploma courses in teacher-librarianship. During the first stage of the study when the collaborative planning sessions occurred, the teacher-librarians were taking their fourth diploma course, a course on information technology in the library program.

\section{Research Setting: The Schools}

The schools in which the pre-service teachers did their practicum were located in a rapidly developing rural community approximately 30 miles from a major urban center. The district has become the eighth largest district in the province, with 34 elementary and 8 secondary schools and a combined city-township population of 97,750 . With increased urbanization a few schools, including one in this study, have been designated as community schools with extra support for families living in low-income housing. The four elementary schools in this study ranged in age from 2 to nearly 20 years. Their school populations were $258,285,368$, and 430 . With new Ministry requirements some teacher-librarian positions were enlarged and created; many of these had previously been cut throughout most of the 1990's. An emergency hiring situation exists in the district, and despite new legislation teacher-librarians remain uncertain about how long this new security will be in effect. 


\section{Information Literacy Project Experiences}

The term before the project started, Dr. Asselin held a meeting at the district resource center to explain the purpose and procedures of the extension project. In attendance were a district consultant, the district head of library services, two district senior administrators, the university faculty advisor for the 19 pre-service teachers, and two of the participating teacher-librarians. Dr. Asselin then met with the four teacher-librarians before the pre-service teachers came for their collaborative planning sessions to provide all the supporting documents the pre-service teachers were expected to use, including books on inquiry-based learning (Case \& Daniels, 1996, 1999), an information literacy curriculum from a local school district (Bens, 1999), a copy of the full assignment on developing an integrated resource-based unit, and Ministry of Education criteria for evaluating different types of resources. The teacher-librarians were also given the topics that the pre-service teachers in their schools had selected for their unit plans. Thus when the pre-service teachers arrived for the collaborative planning sessions, the teacherlibrarians had already pulled numerous resources for them and constructed bibliographies. All planning sessions were held on one day, and teacher-librarians were given release time to work with the pre-service teachers. Because of course schedules, most of the pre-service teachers had only one time to work with their teacher-librarian. To ensure that they accomplished as much as possible, Dr. Asselin, a teacher-librarian from the university who had worked in the project for three years, and a graduate teaching assistant who worked in the project this year each went to one of the three sites to help during the planning sessions and to facilitate the group interviews. Some preservice teachers did return on their own time to work in their school library, and the teacher-librarians followed up with calls to Dr. Asselin when they found additional resources for particular students.

\section{Research Instruments and Procedures}

Data were collected from the pre-service teachers using pre- and post-experience concept maps and structured group interviews. Teacher-librarians also participated in the group interviews with the pre-service teachers in their schools.

Prior to the school experiences, the pre-service teachers, as part of their language arts course, composed a concept map representing their understandings of three major concepts: collaborative planning and teaching, resource-based learning, and information literacy. These three concepts were selected as the key cognitive anchors of the experiences that would follow and the concepts that would best prepare these future teachers to work as instructional partners with teacher-librarians. The pre-service teachers were already familiar with concept maps as a strategy for organizing and representing knowledge. They were given a blank sheet of paper and directed to use as few or as many maps as they needed to represent their understanding of the three concepts. They were given ten minutes of class time to complete the task. The same procedure was repeated at the end of the course. 
There were two interviews with the pre-service teachers, one upon completion of the planning sessions during the course term and another during or following implementation of their unit plans in the schools. To date the first session of interviews has been completed and follow-up interviews have been scheduled for early June. Group interviews were conducted with both the pre-service teachers and teacher-librarians in the four schools where the 19 pre-service teachers had been placed. The following openended questions guided the initial interviews:

1. What understandings about collaboration, resource-based learning, and/or information literacy have been confirmed, extended, and/or revised?

2. What new understandings have begun to develop?

3. What questions do you wish to pursue?

Questions for the second interview focused upon:

1. Development of understandings and practices related to collaboration, resource-based learning, and/or information literacy,

2. Conditions facilitating or impeding implementation of collaboratively planned units, and

3. Observations of effects of collaboration on student learning opportunities and outcomes.

\section{Findings}

\section{Data Analysis}

A strike by university support staff prevented 4 of the 19 pre-service teachers from completing their pre-experience concept maps, and analysis was based on maps from the remaining 15 pre-service teachers. Pre- and post-experience concept maps were analyzed quantitatively and qualitatively by adapting concept-mapping techniques (Trochim, 1989). Adaptations included the elimination of the sorting task by participants, the use of non-statistical methods to categorize data, and the use of t-tests to examine pre-and postexperience knowledge differences. Analysis of the pre- and post-experience concept maps included counting the total number of "branches" directly off each of the three target concepts (primary branches), the total number of sub-categories for each of these branches (secondary branches), and the number of linkages among the three concepts. Figures 1 and 2 show examples of pre- and post-experience concept maps and designations of primary and secondary branches, and linkages. 


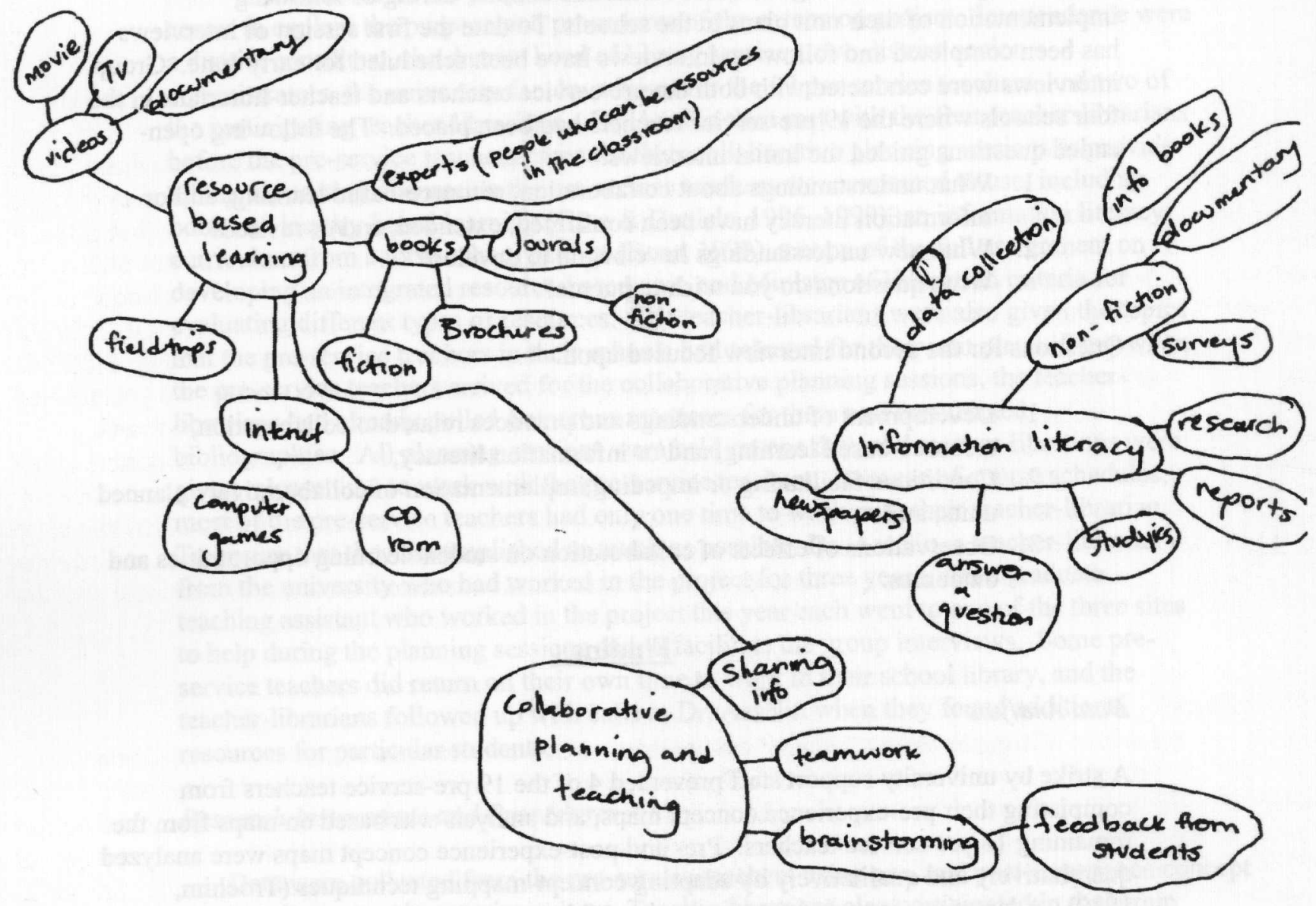

Figure 1. Pre-Concept Map representing primary and secondary branches. 


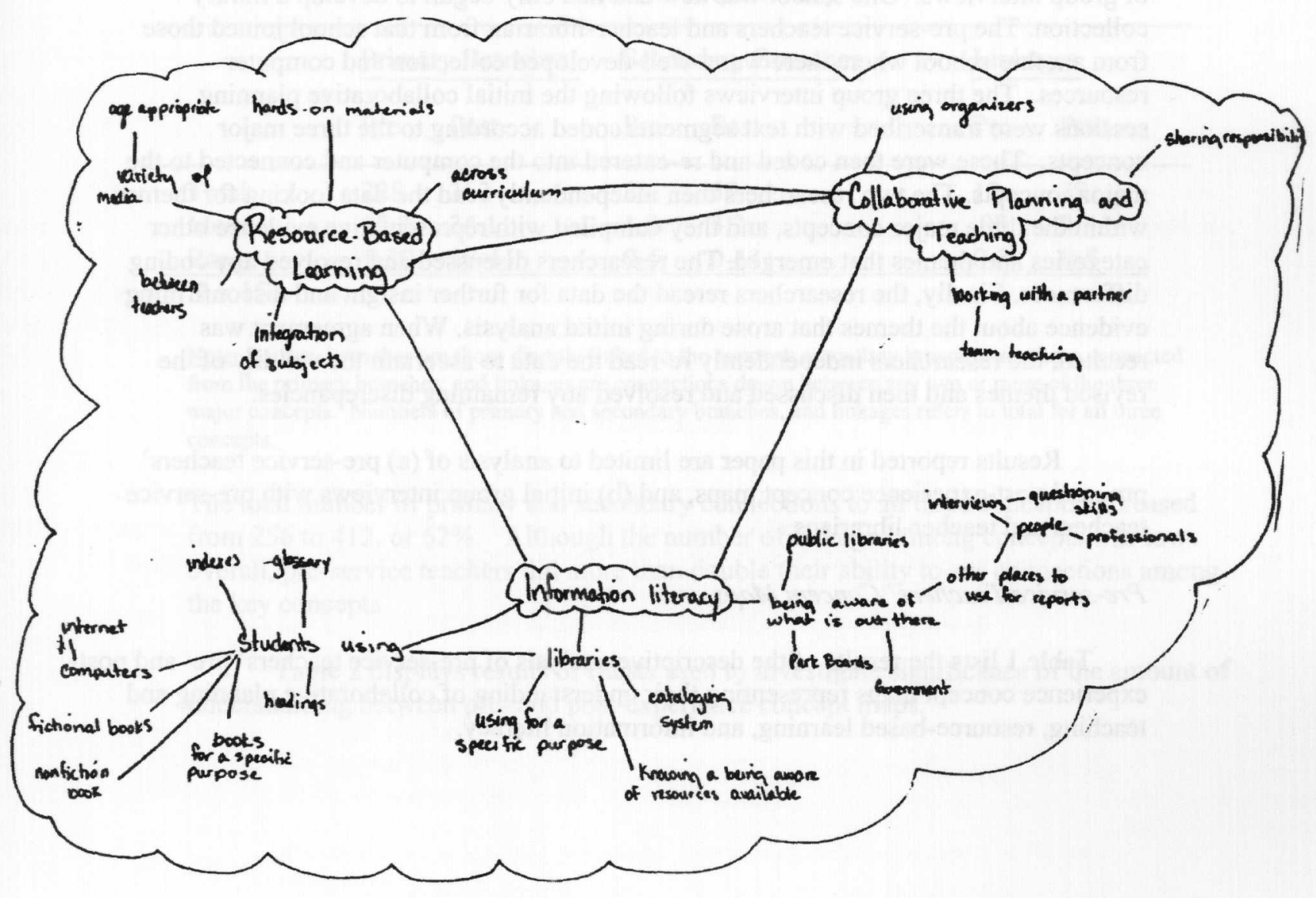

Figure 2. Post-Concept Map representing primary and secondary branches, and linkages. 
Descriptive analysis of the total number of primary and secondary branches and linkages was followed by one-sample t-tests with two-tailed to determine changes in the amount of pre-service teachers' understanding of each of the three major concepts.

All 19 pre-service teachers and 4 teacher-librarians participated in the first session of group interviews. One school was new and had only begun to develop a library collection. The pre-service teachers and teacher-librarian from that school joined those from another school where there was a well-developed collection and computer resources. The three group interviews following the initial collaborative planning sessions were transcribed with text segments coded according to the three major concepts. These were then coded and re-entered into the computer and connected to the major concepts. The two researchers then independently read the data looking for themes within the three major concepts, and they compiled with representative evidence other categories and themes that emerged. The researchers discussed and resolved any coding differences. Finally, the researchers reread the data for further insight and disconfirming evidence about the themes that arose during initial analysis. When agreement was reached, the researchers independently re-read the data to ascertain the validity of the revised themes and then discussed and resolved any remaining discrepancies.

Results reported in this paper are limited to analysis of (a) pre-service teachers' pre- and post-experience concept maps, and (b) initial group interviews with pre-service teachers and teacher-librarians.

\section{Pre-service Teachers' Concept Maps}

Table 1 lists the results of the descriptive analysis of pre-service teachers' pre- and postexperience concept maps representing their understanding of collaborative planning and teaching, resource-based learning, and information literacy. 


\section{Table 1}

Total Number, Mean, and Range of

Primary Branches, Secondary Branches, and Linkages Among

Concept Maps Representing Pre-service Teachers' Understanding of

Collaborative Planning and Teaching, Resource-based Learning, and Information Literacy

\begin{tabular}{|c|c|c|c|c|c|c|}
\hline & \multicolumn{2}{|c|}{ Primary Branches } & \multicolumn{2}{|c|}{ Secondary Branches } & \multicolumn{2}{|c|}{ Linkages } \\
\hline & Pre & Post & Pre & Post & Pre & Post \\
\hline Total & 228 & 362 & 28 & 50 & 12 & 29 \\
\hline Mean & 15.2 & 24.1 & 1.8 & 3.3 & .08 & 2 \\
\hline Range & $1-29$ & $10-41$ & $0-5$ & $0-11$ & $0-3$ & $0-5$ \\
\hline
\end{tabular}

Note: Primary branches are those directly linked to the concept; secondary branches are those connected from the primary branches; and linkages are connections drawn between any two or more of the three major concepts. Numbers of primary and secondary branches, and linkages refers to total for all three concepts.

The total number of primary and secondary connections to all three concepts increased from 256 to 412 , or $62 \%$. Although the number of linkages among concepts was low overall, pre-service teachers did more than double their ability to see connections among the key concepts.

Table 2 displays results of t-tests used to investigate significance of the amount of understanding between pre- and post-experience concept maps. 


\section{Table 2}

T-Test Analysis of Pre- and Post-experience Concept Maps

\begin{tabular}{llllll}
\hline $\begin{array}{l}\text { Connection } \\
\text { Level }\end{array}$ & df & Mean & SD & t-value & $\mathrm{p}$ \\
\hline Primary & 14 & 9.07 & 9.1 & 3.54 & $.003^{*}$ \\
Secondary & 14 & 1.60 & 2.95 & 2.10 & .05 \\
Linkages & 14 & 1.27 & 1.22 & 4.01 & $.001^{*}$ \\
\hline
\end{tabular}

$\mathrm{N}=15, *$ Significant at $\mathrm{p}<.05$, two-tailed.

At the .05 level of significance, the results of t-tests show that there was a statistically significant increase in pre-service teachers' knowledge of collaborative planning and teaching, resource-based learning, and information literacy at the primary connection and linkage levels. The increase in amount of secondary branches approached (.05) but did not reach significance.

\section{Group Interviews}

Results from the first session of interviews are summarized in Table 3 and show the emergent knowledge about the three target concepts plus an additional concept that arose regarding learning and teaching conditions for integrated information literacy instruction. 
Table 3

Knowledge of Collaboration, Resource-based Learning, and Information Literacy: Teacher-librarians and Pre-service Teachers

Concept

Knowledge about Concept

Collaboration

Method for extending, enriching, and focusing ideas

Teacher-librarians' knowledge of resources and student abilities makes planning more realistic

Teacher-librarians can be mentors

Collaboration process as problem solving

Resource-based

Available resources influence teaching ideas and objectives

Learning

Information Literacy

Composed of concrete skills

Learning and Teaching

School culture of collaboration

Conditions

Flexible scheduling

$\mathrm{N}=19$ students and 4 teacher-librarians

Pre-service teachers appeared to gain the most new understandings about the concept of collaboration from their first experiences in collaborative planning. They spoke about collaboration as a way of extending and enriching ideas:
All of sudden we had a whole bunch of things we could go from rather than just a small set of ideas we had on our own.
[The teacher-librarian was able] "to give us different teaching strategies and ideas that
maybe we've never used or seen.
It leads you to a new place you might not have thought about-gives you a whole new perspective.

Teacher-librarians confirmed these insights: "I find that in school, people do collaborate because you are going to make that unit much more rich if you can work with someone rather than just try it alone."

In addition to extending a person's ideas, pre-service teachers also noted that collaboration helped them focus ideas that were initially too vague or large to actually write down. One pre-service explained that "rather than my first idea . . . I'm going to have them do research on what I've taught them in government...." One student found the collaboration experience to be "more realistic--just to be able to say, 'this is what I'm thinking - is it too much? Too little? Am I heading the right way?" " 
The pre-service teachers learned that the teacher-librarians' knowledge of both the resources and the abilities of students in their practicum classes made the assignment of planning an integrated unit more realistic:

... you have the background knowledge of the children.

... within five minutes, I had two tables filled with books that were exactly what I needed and wanted.

Although the pre-service teachers did not directly refer to collaborative planning as a problem solving process, the teacher-librarians did. Referring to the collaborative planning experiences with the pre-service teachers or their past experiences with other teachers, the teacher-librarians described this process as negotiating a fit between available resources and ideas or between contrasting perspectives on teaching and learning:

That's part of collaboration-finding a solution.

... a journey into collaboration because you may be coming at things from totally

opposite points of view ....

While the pre-service teachers revealed new insights about collaborative planning related to the teacher-librarian's ability to focus and extend ideas as well as customize teaching ideas to available resources and students' competencies, the teacher-librarians also demonstrated how they support new teachers. During one of the interviews, one preservice teacher revealed her concerns about integrated learning units as an approach that might actually bore students because of the breadth and depth covered about a single topic. The following exchanges represent how teacher-librarians assisted these less experienced pre-service teachers (words in parenthesis added for clarification):

TL-1: I have done this (the integrated unit) before (as a teacher). Every afternoon was whales. I incorporated everything: science, math, art, language arts, reading, silent reading-everything we did was around it and it was exciting. The kids really enjoyed it.

S-4: They didn't get bored? . . They didn't always hate you for making them study whales?

TL-1: No, they like whales, they like dolphins.

\section{Resource-based Learning}

Although the pre-service teachers had been involved in short practicum experiences in term one and during the first two weeks of term two, this was the first time they had spent any time in their school library. This experience seemed to impress upon them the different resources available in their schools and at the university and the role of available resources in unit planning. One pre-service teacher exclaimed, "There's just so much information out there .... This is like taking the information you have and making it so much more useful." 
Although the pre-service teachers had been introduced to the district resource center the previous term, they did not have a specific context for its use at that time. During the collaborative planning sessions, the teacher-librarians showed students how to access and navigate the district resource database. One pre-service teacher explained that "realizing that not only are there supporting resources, but basically a whole class set of novels there-whenever they want-that's really, really helpful." Another remarked that seeing the resources in her school changed her unit focus:

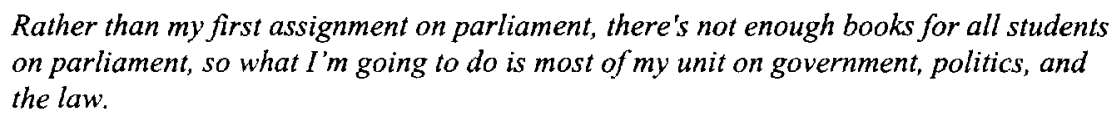

One of the teacher-librarians concluded from the pre-service teachers' discussion of the role of resources in planning that "it is much easier to go from resources to plan than from plan to resources..."

Finally, pre-service teachers commented that becoming familiar not only with the resources in their school library but also their organization was helpful. Two teacherlibrarians confirmed how important this was, adding they were finding that "there is a whole generation of teachers out there that aren't really library literate."

\section{Information Literacy}

Although pre-service teachers commented least about information literacy, they noted that the collaborative planning experience helped them begin to understand what information literacy actually is: "The whole idea makes a lot more sense after you work one on one." Another pre-service teacher discovered that "there is actually a library skills book that you can use to kind of keep yourself on track."

Finally, a few pre-service teachers remarked on specific aspects of information literacy they had learned from the planning sessions such as search engines for children and teaching tools for helping students to evaluate web sites.

\section{Learning and Teaching Conditions for Integrated School Library Programs}

As the teacher-librarians responded to the pre-service teachers' queries and explanations of their emergent understandings, they identified two factors that support strong library programs: a school culture of collaboration (Oberg, 1999), and time for teachers and teacher-librarians to collaboratively plan and teach.

All four teacher-librarians pointed to the importance of a collaborative school community. One teacher-librarian had worked in contrasting school environments over her career and saw her present situation as most desirable: "This is a really good school in 
terms of support.... Everybody's very encouraging, very helpful." Another teacherlibrarian explained that collaboration "grows in a school ... where you get to know people, you get to collaborate." She described the different degrees of fit that teacherlibrarians have with their schools' teachers and how "what you do in your unit depends on your philosophical basis and your thoughts about learning."

The teacher-librarians also unanimously identified time as a central issue in carrying out what they would really like to be doing: "This is something I wish I could do, you know, all the time; it's hard because of all the extra time. Similarly, another teacher-librarian explained that "ideally it would be nice .... it depends if there is time set aside for that; the situation in most libraries in schools is that you have back-to-back prep; there are classes in all day." She went on to explain that teaching information literacy collaboratively with teachers is "a new thing ...." Time was not always such a critical factor in this district as one teacher-librarian reflected on her many years of experience: "We really notice the years that there hasn't been the time or even the opportunity to teach information literacy and it hasn't been taught in the classroom."

\section{$\underline{\text { Discussion }}$}

Analysis of both the pre-service teachers' concept maps and the group interviews with teacher-librarians and pre-service teachers together suggest that pre-service teachers see the school library as more than a warehouse and the teacher-librarian as having some valuable roles to play in the success of their own teaching. Teacher-librarians appeared to rekindle their beliefs about their preferred roles as partners in curriculum design, implementation, and evaluation.

Preliminary analysis of the pre-service teachers' concept maps indicates that when pre-service teachers work with teacher-librarians in authentic contexts, they significantly increase their understandings of resource-based learning, information literacy, and collaborative planning and teaching--the three concepts underlying current school library visions in both Canada (ATLC \& CSLA, 1997) and the United States (AASL \& AECT, 1998). Knowing more about these concepts may better prepare the pre-service teachers in this study to form instructional partnerships with teacher-librarians in their future schools. Qualitative analysis of concept map data is needed to reveal the particular ways that pre-service teachers expanded their knowledge about these central aspects of school library programs.

Analysis of the first interview session data indicates that even at this early stage of the process, the authentic experience of working in their practicum school libraries with the school's teacher-librarian made abstract notions begin to come to life:

I understand more and how collaborative planning would be to me.

I can't say I would have thought to have the teacher-librarian as a resource in a way that it is possible to. 
The interviews suggest that pre-service teachers were moving towards conceptions about collaboration, resource-based learning, and information literacy that are consistent with the professional literature. They talked most about what it means to collaborate with teacher-librarians because that was a salient feature of the planning sessions and something completely new to them. The pre-service teachers had previously worked with their school advisor during an earlier two-week practicum, but collaborative planning had not been explicitly addressed at that time. From the planning sessions they appeared to gain insight into the teacher-librarian's collaborative role as builder and focuser of ideas as pertinent to resources and students' abilities, competencies identified in current guidelines (AASL \& AECT, 1998; ATLC \& CSLA, 1997).

Teacher-librarians, on the other hand, echoed the professional literature on the implementation of curriculum-based school library programs (McCarthy, Zweizig \& Hopkins, 1999) when they spoke about critical variables for successful collaboration such as flexible schedules that provide time to plan and teach and, by implication, teacher commitment. They likely stressed scheduling or time because of the lack of these conditions in their own working environments. Webb (1999) describes these conditions (fixed schedules) as contrary to supporting constructivist approaches to teaching and learning; fixed schedules mean that when students are dropped off at the library once a week, teachers use the time for their own planning or grading rather than instruction and students use the time more for checking out books than for learning. By contrast, flexible scheduling, where classes are scheduled for instruction based on instructional need rather than a fixed calendar, significantly affects the amount of collaboration and information literacy instruction (VanDeusen \& Tallman, 1994).

The extension of the Information Literacy Project into the schools seemed to bring out both frustration with the present and a reminder of what should be for the teacher-librarians in this study:

Just sitting here planning stuff- that's what I want to be doing--not covering preps! I do teach the Dewey decimal system and research skills and how to use an encyclopedia, and all that which is very important. But this makes it more realistic.

\section{Conclusions}

Student learning is at the heart of all current educational reforms. Collaboration is a key factor of effective schools (Taylor et al., in press) and a focus of school reform (Fullan, 1991, 1993). Collaborative planning, teaching, and evaluating with teachers for the purpose of supporting students' learning in curricular areas and in developing those information literacy skills required to become independent lifelong learners have been the center of school library programs for most of the latter half of the $20^{\text {th }}$ century. The extension of the Information Literacy Project described in this paper was designed for new teachers so they could experience this kind of collaboration before becoming acculturated to view teaching as "an individual craft" (Clark et al., 1996, p. 217). True collaboration is the goal and ideal: 


\begin{abstract}
The principles in a true collaboration represent complementary domains of expertise. As collaborators, they not only plan, decide, and act jointly but also think together, combining independent conceptual schemes to create original frameworks. Also, in a true collaboration, there is a commitment to shared resources, power, and talent; no individual's point of view dominates, authority for decisions and actions resides in the group, and work products reflect a blending of all participants' contributions. (Minnis, John-Steiner, \& Weber, 1998, p. C-2)
\end{abstract}

There are several limitations concerning what pre-service teachers in this project came to understand about the teacher-librarian as instructional partner and the nature of an integrated school library program. First, their collaborative experiences were limited to the planning of instructional resource-based units. Other collaborative experiences with teacher-librarians such as selecting a collection of learning resources, teaching and evaluating specific lessons, and developing an overall school library program were missing. Second, inequities between the collaborating partners in the project-preservice teachers and teacher-librarians--existed with respect to their experience and status. This made true collaboration unlikely. However, evidence of a mentoring relationship between pre-service teachers and the teacher-librarians was gleaned from the interviews, and this could be an effective strategy for supporting new teachers' professional development. Finally, conditions in the districts did not support the likelihood that the integrated, collaboratively planned units would be fully implemented or that the pre-service teachers would see collaboration with the teacher-librarian as part of their school cultures (Pickard, 1993).

Further studies could examine the nature of the collaboration during the project and the conditions that best bring about the ideal complementarities described by Minnis et al. (1994). More attention should be paid to factors ensuring (a) ownership of the collaborative process by all participants, (b) balancing benefits of collaboration with intensification of teacher and teacher-librarian work, and (c) authentic as opposed contrived models of collaboration (Gitlin, 1999). Other topics to investigate about teacher's pre-service and in-service years include the effects of teacher and teacherlibrarian collaboration on student learning opportunities and outcomes (Kuhlthau, 1999; Lance, Welborn, \& Hamilton-Pennell, 1993), and teaching satisfaction (Clark et al., 1996).

The extension of the Information Literacy Project into the schools represents a professional development program not only for pre-service teachers but also for inservice teacher-librarians, teachers, and administrators. Such a project maximizes the potential of universities to participate in educational change through professional development (Doiron, 1999; Loucks-Horsley, Herson, Love, \& Stiles, 1998). Plans are underway to continue the types of partnerships described in this study between teacher education programs and school districts to prepare new teachers for instructional partnerships with teacher-librarians. One improvement would be to increase the continuity of university support of the language arts course and practicum term. Hectic schedules for all the participants meant that the researchers were not able to return to the schools for follow-up until several months after the collaborative planning sessions. It would be valuable for this to evolve into a true action research structure for the teacher- 
librarians with more ongoing connections with the university. Teachers need to be invited into the partnership from the early stages as well. Although the partnership in this study was originally planned as a triad between teacher-librarian, pre-service teachers, and school advisors, scheduling difficulties left the teachers out this year. Finally, this study needs to be replicated in other districts where populations, resources, political climate, and other variables exist.

\section{References}

American Association of School Librarians. (1995). Competencies for prospective teachers and administrators. Chicago: American Library Association.

American Association of School Librarians. (1999). Information literacy: A position paper on information problem solving. Available on-line: http://www.ala.org/aas1/positions/ps_infolit.html [2000, May 23].

American Association of School Librarians \& Association for Educational Communications and Technology. (1988). Information Power: Guidelines for school library programs. Chicago: American Library Association.

American Association of School Librarians \& Association for Educational Communications and Technology. (1998). Information power: Building partnerships for learning. Chicago: American Library Association.

American Library Association Presidential Committee on Information Literacy. (1989). Final report. (ERIC Document Reproduction Service No. ED 315 074). Available online: http://www.infolit.org/documents/89Report.htm [2000, May 23].

Asselin, M. (1999). Planting the seeds of instructional partnerships: An exploratory study of pre-service teachers learning to teach with teacher-librarians. In J. Henri \& K. Bonanno (Eds.), The information literate school community. Wagga Wagga, Australia: Centre for Information Studies.

Asselin, M. (2000, August) Advocacy from the start: A case study of pre-service teachers and teacherlibrarians learning to work together. Manuscript submitted for publication. Proceedings of the International Association of School Librarians, Malmo, Sweden.

Asselin, M. (in press). Poised for change: Effects of a teacher education project on pre-service teachers' knowledge of the school library program and role of the teacher-librarian. School Libraries Worldwide.

Association for Teacher-librarians in Canada \& Canadian School Library Association (1997). Students' information literacy needs in the $21^{\text {si }}$ century.

Bens, S. et al. (1999). Learning outcomes for information literacy. Coquitlam: School District \#43. Available on-line: http://www.library.ubc.ca/edlib/Learning.html [2000, Jan. 8]

Bertrand, D. et al. (1982). Partners in action: The library resource centre in the school curriculum. Toronto: Ontario Ministry of Education.

Borko, H., \& Putnam, R. (1996). Learning to teach. In R.C. Calfee \& D.C. Berliner (Eds.), Handbook of educational psychology ( $2^{\text {nd }}$ ed., pp. 673-708). New York: Macmillan.

Breivik, P.S., \& Senn, J. A. (1998). Information literacy : educating children for the 21st century. Washington, D.C.: National Education Association. 
British Columbia. Learning Resources Branch. (1991). Developing independent learners: The role of the school library resource centre. Victoria

Canadian School Library Association. (1988). Guidelines for effective school library programs. Occasional Paper \#1. Rationale. Ottawa: Author.

Case, R., \& Daniels, L.R. (Eds.). (1996). Critical challenges for primary students. Richmond, B.C.: Critical Thinking Cooperative.

Case, R. \& Daniels, L.R. (Eds.). (1999). Critical challenges in social studies for upper elementary students. Richmond, B.C.: Critical Thinking Cooperative.

Clark, C. et al. (1996). Collaboration as dialogue: Teachers and researchers engaged in conversation and professional development. American Educational Research Journal, 33 (1), 193-231.

Craver, K.W. (1986). The changing instructional role of the high school library media specialist, 1950 1984: A survey of professional literature, standards, and research studies. School Library Media Quarterly, 14 (4),183-191.

Doiron, R. (1999). Beyond the frontline: Advocating new partnerships in support of school libraries. Teacher Librarian, 26 (3), 9-14.

Dressman, M. (1997). Congruence, resistance, liminality: Reading and ideology in three school libraries. Curriculum Inquiry, 27, 267-315.

Finke, J., \& Edwards, B. (1997). Teacher education students' insights from intergenerational literature circles. Journal of Teacher Education, 48 (5), 367-378.

Forging forward: The national symposium on information, literacy and the school library in Canada. (1997). Available on-line: http://gateway3.uvic.ca/symposium/symposium.html [2000, May23].

Fullan, M.G. (1982). The meaning of educational change. New York: Teachers College Press.

Fullan, M.G. (1993). Probing the depths of educational reform. New York: Falmer.

Gitlin, A. (1999). Collaboration and progressive school reform. Educational Policy, 13(5), 630-659.

Hamilton, D. (1998). The promise, the process and the promise: The national symposium on information literacy and the school library in Canada. Education Canada, 38(1), 5-8.

Haycock, K. (1996). Research in teacher-librarianship and the institutionalization of change. In L.A. Clyde (Ed.), Sustaining the vision: A collection of articles and papers on research in school librarianship (pp. 13-23). San Jose, CA: Hi Willow Research \& Publishing.

Jackson, S.L., Herling, E.B., \& Josey, E.J. (Eds.). (1976). A century of service: Librarianship in the United States and Canada. Chicago: American Library Association.

Kuhlthau, C.A. (1999). Student learning in the library: What Library Power librarians say. School Libraries Worldwide, 5(2), 80-97.

Lance, K.C., Welborn, L., \& Hamilton-Pennell, C. (1993). The impact of school library media centers on academic achievement. Castle Rock, $\mathrm{CO}$ : Willow Research and Publishing.

Loertscher, D.L. (1988). Taxonomies of the school library media program. Englewood, CO: Libraries Unlimited. 
Loucks-Horsely, S., Herson, P.W., Love, N., \& Stiles, K.E. (1998). Designing professional development for teachers of science and mathematics. Thousand Oaks, CA: Corwin Press.

McCarthy, C.A. (1997). A reality check: The challenges of implementing Information Power in school library media programs. School Library Media Quarterly, 15, 205-214.

Minnis, M., John-Steiner, V., \& Weber, R.J. (1998). The challenge of studying collaboration. American Educational Research Journal, 35(4), 773-783.

Moore, P. (2000). Primary school children's interaction with library media: Information literacy in practice. Teacher-Librarian, 27(3), 7-11.

National Center for Education Statistics. (1994). School library media centers in the United States 199091. Washington, D.C.: U.S. Department of Education, Office of Educational Research and Improvement.

National Forum on Information Literacy. (1998). A progress report on information literacy: An update on the American Library Association Presidential Committee on Information Literacy: Final Report. Chicago.

Oberg, D. (1999) The school library program and the culture of the school. In K. Haycock (Ed.), Foundations for effective school library media programs (pp. 41-47). Englewood, CO: Libraries Unlimited.

Pickard, P.W. (1993). The instructional consultant role of the school library media specialist. School Library Media Quarterly, 2l(2),115-121.

Powell, R.R. (1996). Epistemological antecedents to culturally relevant and constructivist classroom curricula: A longitudinal study of teachers' contrasting world views. Teaching and Teacher Education, 12(4), 365-384.

Short, K.G. et al. (1996). Learning together through inquiry: From Columbus to integrated curriculum. New York: Stenhouse.

Shulman, L.S. (1987). Knowledge and teaching: Foundations of a new reform. Harvard Educational Review, 57, 1-22.

Taylor, B., Pearson, P.D., \& Richardson, V. (in press). Beating the odds in teaching all children to read. Elementary School Journal.

Trochim, W. (1989). An introduction to concept mapping for planning and evaluation. Evaluation and Program Planning, 12, 1-16.

VanDuesen, J.,\& Tallman, J. (1994). The impact of scheduling on curriculum consultation and information literacy skills instruction. School Library Media Quarterly, 23, 17-26.

Webb, N.L. (1999). Collaboration. In D.L. Zweizig \& D.M. Hopkins, Lessons from Library Power: Enriching teaching and learning (pp. 53-78). Englewood, CO: Libraries Unlimited.

Wolf, S.A., Carey, A.A., \& Mieras, E.L. (1996). "What is this literachurch this anyway?" Preservice teachers' growth in understanding children's literary response. Reading Research Quarterly, $31(2), 130-157$.

Zweizig, D.L., \& Hopkins, D.M. (1999). Lessons from Library Power: Enriching teaching and learning. Englewood, CO: Libraries Unlimited. 